\title{
VERIFYING THE INFLUENCE OF THE CYTOPLASM ON THE REGENERATION ABILITY IN SUNFLOWER
}

\author{
Cravero, V. ${ }^{*}{ }^{1}$, Nestares, G. ${ }^{2}$, Zorzoli, R. ${ }^{2}$ and Picardi, L. ${ }^{2}$ \\ ${ }^{1}$ CONICET, Cátedra de Mejoramiento Vegetal, Facultad de Ciencias Agrarias, Uni- \\ versidad Nacional de Rosario, CC 14 (S2125ZAA) Zavalla, Santa Fe, Argentina. \\ ${ }^{2}$ Cátedra de Genética, Facultad de Ciencias Agrarias, Universidad Nacional de \\ Rosario, CC 14 (S2125ZAA) Zavalla, Santa Fe, Argentina.
}

Received: May 26, 2012

Accepted: June 10, 2012

\begin{abstract}
SUMMARY
Sunflower in vitro culture regeneration is highly dependent on the genotypic context and culture conditions. However, there is insufficient information about the effect of the cytoplasm on the regeneration ability of this species. The aim of this experiment was to evaluate the effect of different cytoplasmic background on the regeneration ability of HA89, a well known recalcitrant inbred line. Cotyledons of seven HA89-alloplasmic lines and the fertile HA89 inbred line were used as explants on four different culture media. After 36 days of incubation, the regeneration percentage, as well as the productivity and proliferation rates, was recorded. Genotype $\times$ culture media interaction was detected in order to obtain regeneration percentage. Further analysis of this interaction demonstrated that the effect of the cytoplasm and the resulting interactions with the culture medium are key factors to be taken into account for better understanding of the in vitro culture performance of this species. Furthermore, non-nuclear genome could be considered as another source of variability modifying the regeneration ability of recalcitrant sunflower genotypes.
\end{abstract}

Key words: alloplasmic lines, AMMI models, Helianthus annuus L., in vitro culture

\section{INTRODUCTION}

Cytoplasmic male sterility ( $\mathrm{cms}$ ) in plants is defined as the maternally-inherited inability to produce functional pollen due to the mitochondrial (mt) genome constitution (Schnable and Wise, 1998). Male sterility is very useful for the production of hybrid seeds in cultivated species. Commercial sunflower hybrids are generally obtained using a single source of $\mathrm{cms}$, PET1, which originates from cross-breeding between Helianthus petiolaris and Helianthus annuus (Leclercq, 1969). Recently, several $\mathrm{cms}$ backgrounds have been developed by intraspecific and interspecific

* Corresponding author: e-mail: vcravero@unr.edu.al; Phone: +54 3414970080 
crosses, which resulted in more than $70 \mathrm{cms}$ sources being available at the moment (Serieys, 2002). Since these $\mathrm{cms}$ sources were identified, several experiments to estimate the influence of the cytoplasmic effect on important agronomic traits have been developed before their introgression into commercial breeding programs.

In vitro tissue culture has a great potential to be used in the process of breeding several species, given the availability of an efficient in vitro tissue culture protocol. Even though sunflower is known as recalcitrant to in vitro regeneration techniques (Rákosy-Tican et al., 2007), fertile plants have been regenerated by organogenesis or somatic embryogenesis using different explants such as hypocotyls, leaves, cotyledons, meristematic apexes and immature zygotic embryos (Kallerhoff and Alibert, 1996; Fambrini et al., 2001; Vega et al., 2007; Mayor et al., 2010). Furthermore, several studies demonstrated that regeneration ability of these species depends on the genotype and the culture conditions (Nestares et al., 1996; Baker et al., 1999).

The effect of the nuclear genome on the regeneration ability in sunflower has been well documented (Nestares et al., 1996; Nestares et al., 2001; Mayor et al., 2006). However, there are few reports about the cytoplasmic effect on the in vitro organogenesis. Nestares et al. (1998) found significant differences for regeneration ability between the male-sterile and male-fertile cytoplasmic states of a representative set of sunflower inbred lines, suggesting that cytoplasmic genes affect the expression of this trait.

The effect of different cytoplasmic sources in the in vitro response has been described in other crops as well, such as maize, barley, wheat, and potato (Nesticky et al., 1983; Powell, 1988; Orlov and Pavilova, 1989; Singsit and Veilleux, 1989; Frei, 2003) suggesting that, besides environmental conditions, the nuclear and maternal inherited genome may modify the regeneration ability of sunflower. In this study, the effect of different cytoplasmic background on the regeneration ability in sunflower was assessed under different in vitro culture conditions.

\section{MATERIALS AND METHODS}

\section{Plant material}

Seven alloplasmic lines with the nuclear genotype HA89 were evaluated for their in vitro performance. The evaluated cytoplasms and their origins were as follows: RES1 (H. resinosus), PEF1 (H. petiolaris ssp. Fallax), RIG (H. rigidus), MAX1 (H. maximiliani); fertile cytoplasm (H. annuus), PET1 (H. petiolaris), PET2 (H. petiolaris) and GIG1 (H. giganteus). The alloplasmic lines were developed by implementing introgression of different sources of cytoplasm into an elite inbred line (HA89) using backcrossing (Serieys, 2002). The fertile HA89 inbred line was used as a tester. 


\section{In vitro culture}

Seeds without pericarps were surface-sterilized in $98 \%$ ethanol for $30 \mathrm{sec}$, soaked in 5\% sodium hypochlorite for $15 \mathrm{~min}$, and then rinsed three times in sterile distilled water. The sterile seeds were germinated on the half-strength Murashige and Skoog's (MS) (1962) medium supplemented with $10 \mathrm{~g}^{-1}$ of sucrose and solidified with $9 \mathrm{~g} \mathrm{l}^{-1}$ of agar. Seeds were kept in darkness at $25 \pm 2^{\circ} \mathrm{C}$ for 2 days before being transferred to light $\left(25 \pm 2^{\circ} \mathrm{C}\right.$ and $12 \mathrm{~h}$ photoperiod) for another 2 days.

Cotyledons were used as explants and placed on four different culture media. Each medium contained base salt, vitamins and iron chelates MS medium supplemented with of $30 \mathrm{~g} / \mathrm{l}$ of sucrose, $6 \mathrm{~g} / \mathrm{l}$ of agar and one of four different growth-regulating combinations:

- A: MS + $1 \mathrm{mg} / \mathrm{l}$ IAA (indol-3-acetic acid) + 2 mg/l Kinetin (6-furfurylaminopurine)

- B: MS + $1 \mathrm{mg} / \mathrm{l} \mathrm{IAA} \mathrm{+} 2 \mathrm{mg} / \mathrm{l} \mathrm{BAP}$ (6-benzylaminopurine)

- C: MS + $1 \mathrm{mg} / \mathrm{l}$ NAA ( $\alpha$-naphthylacetic acid ) $+2 \mathrm{mg} / \mathrm{l}$ Kinetin

- D: MS + $1 \mathrm{mg} / \mathrm{l} \mathrm{NAA}+2 \mathrm{mg} / \mathrm{l} \mathrm{BAP}$

Explants were incubated for 36 days in a growth chamber at $25 \pm 2^{\circ} \mathrm{C}$, under 12 $\mathrm{h}$ daily illumination $\left(50 \mu \mathrm{M} \mathrm{m}^{-1} \mathrm{~s}^{-1}\right)$, in a completely randomized design with 2 replications and 20 explants per replication.

Once the incubation period was completed, the following traits were evaluated:

- Regeneration percentage (RP): (explants that regenerated shoots/total explants) $\times 100$

- Productivity Rate (PROD): number of shoots/total explants

- Prolificity Rate (PROL): number of shoots/explants that regenerated shoots

\section{Data analysis}

What the data did not show was a normal distribution, so consequently they were transformed by $(x+0.5)^{1 / 2}$. The transformed data were analyzed by a two-way ANOVA using the following model:

$\mathrm{X}_{\mathrm{ij}}=\mu+g_{i}+\varepsilon_{j}+(g \varepsilon)_{\mathrm{ij}}+e$

where $\mu$ is the experimental mean, $g_{\mathrm{i}}$ is the cytoplasm effect, $\varepsilon_{\mathrm{j}}$ is the culture medium effect, $(g \varepsilon)_{\mathrm{ij}}$ is the cytoplasm-medium interaction effect and $e$ is the experimental error.

The effect of the cytoplasm and different culture media on the regeneration ability were compared using Duncan's Multiple Range Test $(\alpha=0.05)$ on the transformed data. The Additive Main effects and Multiplicative Interaction models (AMMI) were used for further analysis of the genotype by environmental interaction (Gauch, 1988; Zobel et al., 1988; Gauch and Zobel, 1996). AMMI is a particularly relevant analysis used to understand the factors underlying two-way interactions better. In this study, each cytoplasm source was considered as a "genotype" (G) and different culture media were considered as "environments" (M) and both, AMMI1 and AMMI2 
models, were used to analyze the cytoplasm $\times$ culture medium $(G \times M)$ interactions. The general AMMI model equation was as follows (Gauch, 1992):

$$
\text { Yger }=\mu+g_{\mathrm{g}}+\varepsilon_{e}+\sum_{n} \lambda_{n} \gamma_{\text {gn }} \delta_{\text {en }}+\rho_{\text {ge }}+\varepsilon g e r
$$

where the additive part is an ordinary ANOVA that leaves the interaction $(g \varepsilon)$ as a non-additive residual. The multiplicative part of the AMMI model uses PCA (Principal Component Analysis) to decompose the interaction into orthogonal linear combinations (principal components). In this case we use AMMI1 and AMMI2 models for the first and second principal components respectively (Gauch, 1992). ANOVA, AMMI 1 and AMMI2 analysis were performed using InfoGen Software (Balzarini and Di Renzo, 2003).

\section{RESULTS AND DISCUSSION}

The alloplasmic and fertile lines differed in prolificity rate (Table 1A). On average, the RES1 line produced 3.25 shoots per regenerating explants, two and half times more than the mean of others cytoplasms evaluated.

The environmental effect was assessed by different growth-regulating concentrations in the culture media. All genotypes in medium A had higher prolificity and productivity rates (Table $1 \mathrm{~b}$ ). These results suggest that indol-acetic acid and kinetin in the basal medium had a positive effect on the amount of regenerated shoots, regardless of the cytoplasm source considered.

Table 1: Mean values (data no transformed) of Regeneration Percentage (RP), Productivity Rate (PROD) and Prolificity Rate (PROL) of each cytoplasm through all media (section A) and mean values (data no transformed) of all cytoplasm in each medium (section B)

\begin{tabular}{lccc}
\hline Cytoplasm & RP & Section A & PROL \\
\hline RES1 & $23.13 \mathrm{a}$ & $0.66 \mathrm{a}$ & $3.25 \mathrm{a}$ \\
PEF1 & $28.29 \mathrm{a}$ & $0.48 \mathrm{a}$ & $2.46 \mathrm{ab}$ \\
RIG & $25.00 \mathrm{a}$ & $0.30 \mathrm{a}$ & $1.16 \mathrm{~b}$ \\
MAX1 & $41.56 \mathrm{a}$ & $0.24 \mathrm{a}$ & $0.84 \mathrm{~b}$ \\
Fertile cytoplasm & $30.10 \mathrm{a}$ & $0.14 \mathrm{a}$ & $0.84 \mathrm{~b}$ \\
PET1 & $27.50 \mathrm{a}$ & $0.13 \mathrm{a}$ & $1.75 \mathrm{ab}$ \\
PET2 & $31.28 \mathrm{a}$ & $0.50 \mathrm{a}$ & $1.33 \mathrm{ab}$ \\
GIG1 & $28.75 \mathrm{a}$ & $0.37 \mathrm{a}$ & $1.14 \mathrm{~b}$ \\
\hline & & & \\
Culture media & & & $2.39 \mathrm{a}$ \\
A & $25.33 \mathrm{a}$ & $0.74 \mathrm{a}$ & $1.76 \mathrm{ab}$ \\
B & $31.61 \mathrm{a}$ & $0.36 \mathrm{ab}$ & $1.25 \mathrm{ab}$ \\
C & $29.46 \mathrm{a}$ & $0.09 \mathrm{~b}$ & $0.98 \mathrm{~b}$ \\
D & $31.41 \mathrm{a}$ & $0.21 \mathrm{~b}$ &
\end{tabular}

Values followed by the same letter are not significantly different at $p=0.05$ (Duncan's multiple range test) 


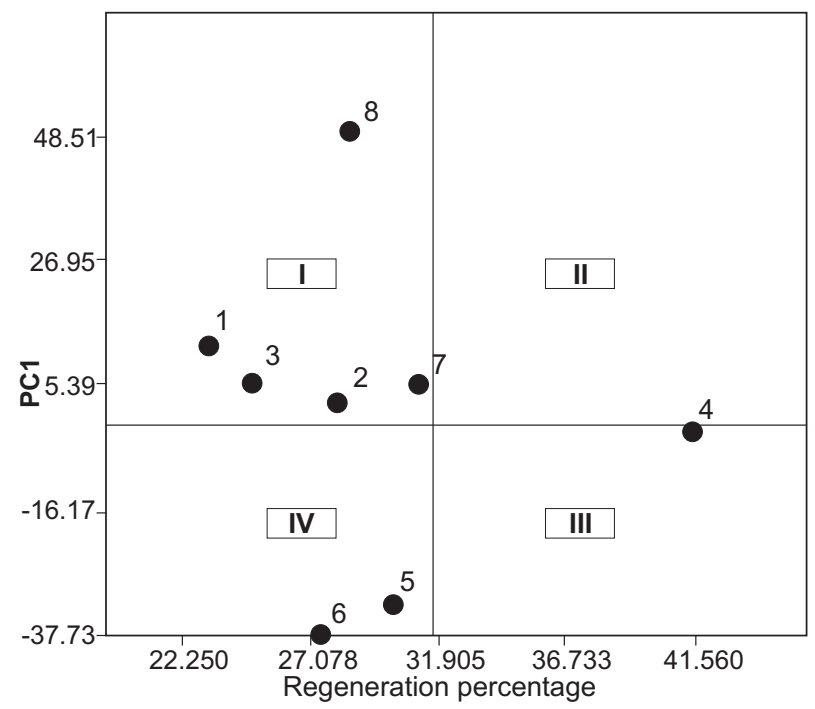

Figure 1: Biplot of the AMMI1 model for the Regeneration Percentage of the eight sunflower lines carrying different cytoplasms and cultured on four regeneration culture media. 1- RES1; 2- PEF1; 3- RIG; 4- MAX1; 5- Fertile cytoplasm; 6- PET1; 7- PET2; 8- GIG1

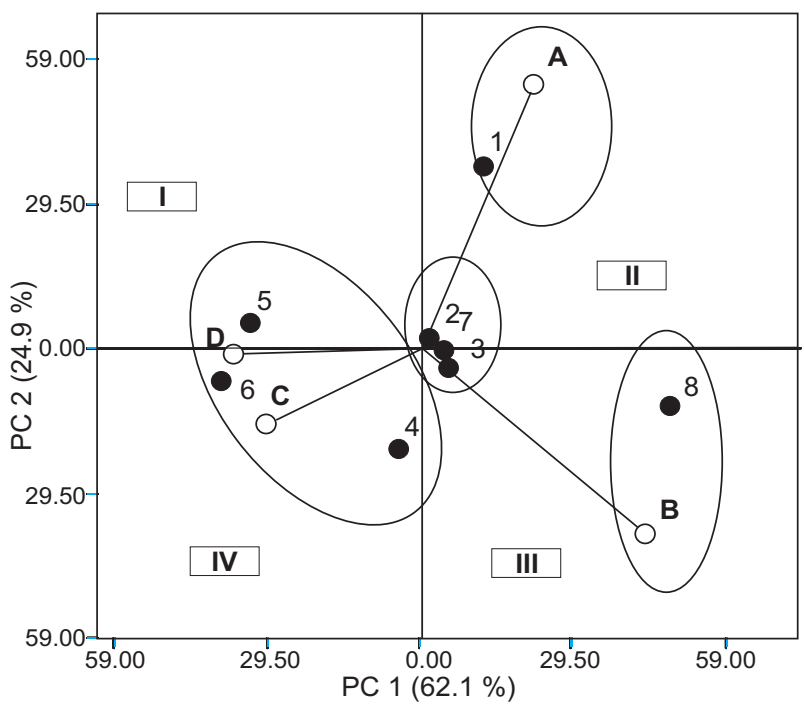

Figure 2: Biplot of the AMMI2 model for the Regeneration Percentage of eight sunflower lines carrying different cytoplasms and cultured on four regeneration culture media.

1-RES1; 2- PEF1; 3- RIG; 4- MAX1; 5- Fertile cytoplasm; 6- PET1; 7- PET2; 8- GIG1

A: Medium A (1 mg/l IAA (indol-3-acetic acid) $+2 \mathrm{mg} / \mathrm{l}$ Kinetin (6-furfurylaminopurine)

B: Medium B (1 mg/l IAA + $2 \mathrm{mg} / \mathrm{l}$ BAP (6-benzylaminopurine)

C: Medium C (1 mg/l NAA ( $\alpha$-naphthylacetic acid ) + 2 mg/l Kinetin)

D: Medium D ( $1 \mathrm{mg} / \mathrm{l} \mathrm{NAA}+2 \mathrm{mg} / \mathrm{l} \mathrm{BAP})$ 
The cytoplasm by culture media interaction was detected for the regeneration percentage $(\mathrm{F}=3.14, \mathrm{p}<0.001)$. Also, the culture medium had an effect on the productivity rates $(\mathrm{F}=6.74, \mathrm{p}<0.001)$.

For further understanding of the $\mathrm{G} \times \mathrm{M}$ interaction for $\mathrm{RP}$, the AMMI 1 and AMMI2 models were used. Biplot display of the AMMI1 analysis is shown in Figure 1 in which the overall mean RP values for the 8 cytoplasms versus the PC1 (First Principal Component) scores were plotted. Genotypes with low regeneration capacity are in quadrants I (RES1; PEF1; RIG; PET2 and GIG1) and IV (Fertile line and PET1) and the genotype with high regeneration ability are in quadrants II and III (MAX1).

The magnitude and the signal of the PC1 scores also must be considered, i.e., scores that are close to zero belong to cytoplasms that have contributed very little to the interaction $(\mathrm{G} \times \mathrm{M})$. Thus MAX1 presented the higher regeneration ability (more than 40\%) and performed as the most stable genotype of the set. Although PEF1, PET2, RIG and RES1 lines have a stable behaviour, they showed weaker regeneration ability than MAX1. The fertile cytoplasm, PET1 and GIG1 lines, had PC1 scores higher than the others cytoplasms. However, they were mostly affected by the culture media growth regulators and therefore should be considered as specifically adapted to specific growth-regulating combinations.

The AMMI2 method not only allows the identification of stable cultivars by visual inspection, but also provides information on the environments. The information obtained from AMMI 2 biplot clearly showed the association between cytoplasms and the culture media presented on the same graph. The first two axes of PC analysis of AMMI 2 explained 87\% of interaction (Figure 2). As Crossa (1990) suggested, the PC1 represents the replicable effects of the $\mathrm{G} \times \mathrm{M}$ interaction, while the PC2 captures those effects with no defined pattern that may be otherwise considered as "noise". The GIG1 line was placed in quadrant III showing that it has good adaptation to culture medium B, as well as RES1 that has good adaptation to medium A. Both media were supplied with the same auxin (IAA) but they differed in the content of cytokinin. Thus, the type of cytokinins and its interaction with cytoplasmic background play a key role in the regeneration of these two alloplasmic lines. On the other hand, MAX1, PET1 and the fertile cytoplasm line had a good response to a greater range of culture media, specially with those that had the auxin NAA, independently of the level of cytokinin used. The most stable lines in this analysis were PEF1, RIG and PET2, followed by MAX1, HA89B and PET1. The lines with the greatest $\mathrm{G} \times \mathrm{M}$ effects were RES1 and GIG1.

Several reports about sunflower regeneration were focused on establishing the ideal concentration of growth regulators and the relationship between auxins and cytokinins (Paterson, 1984; Pugliesi et al. 1991). Also, several results about the interaction between the genotypes and the culture medium in the in vitro culture systems were reported (Barandiarian et al., 1999; Nestares et al., 2002). However, no reports of possible interaction between cytoplasm and culture media have been 
published yet. This study demonstrates that the effect of cytoplasm, together with the nuclear genome and their resulting interactions with the culture medium are key factors to be considered for a better understanding of the in vitro culture in this species.

It is worth noting that the in vitro performance was not influenced by the origin of $\mathrm{cms}$ in this experiment. All the $\mathrm{cms}$ sources evaluated were originated by interspecific cross-breeding between $H$. annuus and other wild relatives such as: $H$. petiolaris (PET1 and PET2), H. petiolaris ssp. fallax (PEF1), H. resinosus (RES), $H$. rigidus (RIG), H. giganteus (GIG1) and $H$. maximiliani (MAX1). The in vitro response observed had little to no relation with the origin of these cytoplasms. It is a well known fact that the PET1 and PET2 come from the same original crossbreeding, whereas PEF originated from the cross-breeding between different subspecies. Horn (2002) demonstrated that PEF1 and PET2 mitochondrial DNA had a clearly different organization than PET1. This fact might be associated with different responses observed in the cms sources used in this experiment. A similar response was observed with PEF1 and PET2, whereas the PET1 response seems to be similar to that observed in the fertile cytoplasm line.

Nestares et al. (1998) have pointed that cytoplasm substitution alone would not enhanced the plant regeneration capacity of recalcitrant genotypes. Nevertheless, the examination of interactions among the cytoplasm, nuclear genome and medium might be necessary for improving the regeneration ability in sunflower.

\section{CONCLUSIONS}

Our results have demonstrated that cytoplasm substitution in a genotype, together with a suitable formulation of the culture medium, must be considered to increase the regeneration ability of recalcitrant genotypes.

\section{ACKNOWLEDGEMENTS}

We are thankful to Drs. M. Echeverría, C.C. Jan and G. Van Becelaere for kindly providing us with the alloplasmic lines. We are also thankful to Dr M.L. Mayor for helpful discussions and comments on the manuscript.

\section{REFERENCES}

Baker, C.M., Muños-Fernandez, N. and Carter, C.D., 1999. Improved shoot development and rooting from mature cotyledons of sunflower. Plant Cell, Tissue and Organ Culture 58: 39-49.

Balzarini, M. and Di Renzo, J., 2003. Info-Gen: Software para análisis estadístico de datos genéticos. Facultad de Ciencias Agropecuarias, Universidad Nacional de Córdoba, Argentina. 
Barandiarian, X., Martín, N., Rodriguez-Conde, M.F., Di Pietro, A. and Martín, J., 1999. Genetic variability in callus formation and regeneration of garlic (Allium sativum L.). Plant Cell Reports 18: 434-437.

Crossa, J., 1990. Statistical analysis of multilocation trials. Adv. Agron. 44: 55-85.

Fambrini, M., Fisichella, M. and Pugliesi, C., 2001. Enhanced morphogenetic potential from in vitro regenerated plants of genus Helianthus: an overview. Recent Research Developments in Plant Biology 1: 35-54.

Frei, U., Peiretti, E.G. and Wenzel, G., 2003. Significance of cytoplasmic DNA in plant breeding. Plant Breeding Reviews 23: 175-210.

Gauch, H.G., 1988. Model Selection and Validation for Yield Trials with Interaction. Biometrics 44: 705-715.

Gauch, H.G., 1992. Statistical Analysis of regional yield trials: AMMI analysis of factorial designs. Elsevier Science Publishers B.V. Amsterdam.

Gauch, H.G. and Zobel, R.W., 1996. AMMI analysis of yield trials. In: Genotype-by-Environment interaction (Kang, M.S., Gauch, H.G., eds). CRC Press: Boca Ratón, pp. 85-122.

Horn, R., 2002. Molecular diversity of male sterility inducing and male-fertile cytoplasms in the genus Helianthus. Theoretical and Applied Genetics 104: 562-570.

Kallerhoff, J. and Alibert, G., 1996. Tournesol et biotechnologie: état actuel et perspectives (Sunflower and biotechnology: current situation and outlook). Oléagineux, corps gras, lipides 3(3): 154-158.

Leclercq, P., 1969. Une stérilité mâle chez le tournesol. Annales de L'amélioration des Plantes 19: 99-106.

Mathias, R.J. and Fukui, K., 1986. The effect of specific chromosome and cytoplasm substitutions on the tissue culture response of wheat (Triticum aestivum) callus. Theoretical and Applied Genetics 71: 797-800.

Mayor, M.L., Nestares, G., Zorzoli, R. and Picardi, L.A., 2006. Analysis for combining ability in sunflower organogenesis-related traits. Australian Journal of Agricultural Research 57(10): 1123-1129.

Mayor, M.L., Nestares, G., Vega, T., Zorzoli, R. and Picardi, L., 2010. Sunflower Propagation. In: Protocols for in vitro propagation of ornamental plants. (Jain S.M., Ochatt S.J. eds). Humana Press and Springer, Totowa, pp. 271-280.

Murashige, T. and Skoog F., 1962. A revised medium for rapid growth a biossays with tobacco tissue cultures. Physiologia Plantarum 15: 473-497.

Nestares, G.M., Zorzoli, R., Mroginski, L.A. and Picardi, L.A., 1996. Plant regeneration from cotyledons derived from mature sunflower seeds. Helia 19: 107-112.

Nestares, G., Zorzoli, R., Mroginski, L. and Picardi, L., 1998. Cytoplasmic effects on the regeneration ability of sunflower. Plant Breeding 117: 188-190.

Nestares, G., Mayor, M.L., Zorzoli, R., Mroginski, L. and Picardi, L., 2001. Combining ability of sunflower inbred lines for in vitro traits. Helia 24(35): 17-24.

Nestares, G., Zorzoli, R., Mroginski, L. and Picardi, L., 2002. Heritability of in vitro plant regeneration capacity in sunflower. Plant Breeding 121: 366-368.

Nesticky, M., Novak, F., Piovarci, A. and Dolezelova, M., 1983. Genetic analysis of callus growth of maize (Zea mays L.) in vitro. Z. Pflanzenziichtg 91: 322-328.

Orlov, P. and Palilova, A., 1989. Modifying influence of alien cytoplasms on callus induction and growth of alloplasmic wheat lines. Genetika 25: 2168-2175.

Paterson, K.E., 1984. Shoot tip culture of Helianthus annuus-flowering and development of adventitious and multiple shoots. Am. J. Bot. 71: 925-931.

Powell, W., 1988. Diallel analysis of barley anther culture response. Genome 30: 152-157.

Pugliesi, C., Cecconi, F., Mandolfo, A. and Baroncelli, S., 1991. Plant regeneration and genetic variability from tissue cultures of sunflower (Helianthus annuus L.). Plant Breeding 106: 114-121.

Rákosy-Tican, E., Aurori, A., Vesa, S. and Kovacs, K., 2007. In vitro morphogenesis of sunflower (Helianthus annuus L.) hypocotyl protoplasts: the effects of protoplast density haemoglobin and spermidine. Plant Cell, Tissue and Organ Culture 90: 55-62.

Schnable, P.S., Wise, R.P., 1998. The molecular basis of cytoplasmic male sterility. Trends in Plant Sciences 3: 175-180.

Serieys, H., 2002. Report on the past activities of the FAO Working Group "Identification study and utilization in breeding programs of new cms sources" for the period 1999-2001, FAO, Rome. 
Singsit, C. and Veilleux, R., 1989. Intra- and interspecific transmission of androgenetic competence in diploid potato species. Euphytica 43: 105-112.

Vega, T.A., Nestares, G.M., Pratta, G., Zorzoli, R., Gattuso, S. and Picardi, L., 2007. Biochemical and histological changes associated with in vitro responses in sunflower cotyledonary explants. In: Vitro Cellular \& Developmental Biology - Plant 43: 415-422.

Zobel, R.W., Wright, M.J. and Gauch, H.G., 1988. Statistical analysis of a yield trial. Agronomy Journal 80: 388-393.

\section{RESUMEN}

La regeneración in vitro del girasol es altamente dependiente del contexto genotípico y de las condiciones de cultivo. Sin embargo, existe muy poca información acerca del efecto del citoplasma sobre la capacidad de regeneración en esta especie. El objetivo de este trabajo fue evaluar el efecto de diferentes fondos citoplásmicos sobre la capacidad de regeneración de la línea endocriada recalcitrante conocida como HA89. Como explantos se utilizaron cotiledones de la línea endocriada HA89 fértil y de siete líneas aloplásmicas, los cuales fueron colocados en cuatro medios de cultivo diferentes. Luego de 36 días de incubación, se calcularon el porcentaje de regeneración, la productividad y la prolificidad. Se determinó la existencia de interacción genotipo $\times$ medio de cultivo para el porcentaje de regeneración. El análisis de esta interacción demostró que el efecto del citoplasma y la interacción con el medio de cultivo son factores clave a considerar para lograr una mejor comprensión del desempeño de esta especie en cultivo in vitro. Además, el genoma no nuclear podría ser considerado como otra fuente de variabilidad que modifica la capacidad de regeneración de genotipos recalcitrantes de girasol.

\section{RÉSUMÉ}

La régénération in vitro du tournesol est très dépendante du génotype et des conditions de culture. »Cependant, il y a très peu d'informations sur l'effet du cytoplasme sur la capacité de régénération de cette espèce. L'objectif de ce travail était d'évaluer l'effet de différents fonds cytoplasmiques sur la capacité de régénération de la ligne consanguine récalcitrant connu comme HA89. Comme explants ont été utilisés les cotylédons de la ligne HA 89 fertile et sept lignes alloplastiques, qui ont été placés dans quatre milieux de culture différents. Après 36 jours d'incubation, nous avons calculé le pourcentage de régénération, de la productivité et de la prolificidad. Nous avons determiné l'existence de l'interaction génotype $\times$ moyenne de culture pour le pourcentage de régénération.

$\mathrm{L}^{\prime}$ analyse de cette interaction a montré que l'effet du cytoplasme et l'interaction avec le milieu de culture sont des facteurs clés à considérer pour atteindre une meilleure compréhension du comportement de cette espèce dans la culture in vitro. Le génome no nucléaire pourrait être considéré comme une autre source de variabilité qui modifie la capacité de régénération des génotypes récalcitrants du tournesol. 
